\title{
Konsep Dan Dinamika Komunikasi Antarbudaya Di Indonesia
}

\author{
Karmilah, Sobarudin \\ Pascasarjana UIN Sunan Gunung Djati Bandung \\ Email:aqautsar@gmail.com
}

\begin{abstract}
Indonesian society is a heterogeneous society because it consists of various cultures, ethnicities, races, languages, religions, and customs. One of them is culture and language in communication carried out by the Indonesian people that are accommodative which become a unifying nation in the frame of diversity. This study aims to determine the message of culture and language in the dynamics of communication in Indonesia. This research is a qualitative research. In accordance with the object of the study, this type of research is included in the library research category. The results of this study illustrate information that the role of accommodating culture and language communication can be an alternative to the problems and solutions that are being faced by the Indonesian people in the problem of disintegration of this nation. The results of this study show that intercultural communication is very important to be understood by the people of Indonesia, which is a multicultural society. Despite this many obstacles and obstacles faced by Indonesian society included stereotypical issues and perspectives on certain cultures and a still high ethnocentric attitude.
\end{abstract}

Keywords : Communication, Culture, Language, Indonesian.

\begin{abstract}
Abstrak
Masyarakat Indonesia merupakan masyarakat beterogen karena terdiri dari berbagai budaya, suku, ras, Bahasa, agama,dan adat istiadat. Salah satunya adalah budaya dan Bahasa dalam komunikasi yang dilakukan oleh masyarakat Indonesia bersifat akomodatif yang menjadi pemersatu bangsa dalam bingkai kebhinekaan.Penelitian ini bertujuan untuke mengetahui pesan budaya dan Bahasa dalam dinamika komunikasi di Indonesia.Penelitian ini merupakan penelitian kualitatif Sesuai dengan obyek kajian penelitian ini, maka jenis penelitian ini termasuk dalam kategori penelitian kepustakaan (library research). Adapun hasil penelitian ini mengambarkan informasi babwa peranan budaya dan Babasa komunikasiyang bersifat akomodatif bisa menjadi alternatif terhadap permasalahanpermasalahan dan solusi pemecahan yang sedang dibadapi oleh bangsa Indonesia dalam masalah disintegrasi bangsa ini.Adapun hasil penelitian ini mununjukan bahwa komunikasi antarbudaya sangat penting dipahami oleh masyarakat Indonesia yang merupakan masyarakat multikultur.Kendati demikian banyak halangan dan rintangan yang dihadapi
\end{abstract}

Jurnal Dakwah dan Komunikasi

IAIN Curup-Bengkulu | E-ISSN: 2548-3366, P-ISSN: 2548-3293

Available online: 
42 | Jurnal Dakwah dan Komunikasi, Vol. 4 , No.1, 2019

oleh masyarakat Indonseia diantaranya masalah streotip dan perspektif terhadap budaya tertentu dan sikap etnosentirmse yang masib tinggi.

Kata Kunci :Komunikasi, Budaya, Bahasa, Indonesia.

\section{Pendahuluan}

Dewasa ini, sering terjadinya kesalahpahaman-kesalahpahaman antar kelompok, suku, agama dan ras serta budaya yang berbeda sering kita lihat di kehidupan masyarakat Indonesia. Masalah utamanya adalah masyarakat Indonesia pada umumnya lebih cenderung menganggap budaya sebagai suatu kemestian, tanpa mempersoalkan lagi (taken for granted), dan juga seringkali kita menggunakannya sebagai standar atau tolak ukur untuk menghakimi budaya-budaya lain. Bila seseorang tidak menyetujui nilainilai kita bukan berarti orang tersebut salah, bodoh atau sinting, namun kita harus mengetahui bagaimana latar belakang orang tersebut jika dilihat dari segi kebudayaannya.

Budaya adalah suatu konsep yang membangkitkan minat. Secara formal budaya didefinisikan sebagai tatanan pengetahuan, pengalaman,kepercayaan, nilai, makna, hirarki,agama, waktu, peranan, hubungan ruang, konsep alam semesta, objek-objek materi dan milik yang diperoleh sekelompok besar orang dari generasi ke generasi melalui individu dan kelompok. Budaya menampakan diri dalam pola-pola bahasa dan dalam bentuk-bentuk kegiatan dan prilaku yang berfungsi sebagai model-model bagi tindakan penyesuaian diri dan gaya komunikasi yang memungkinkan orangorang tinggal dalam suatu masyarakat disuatu lingkungan geografis tertentu pada suatu tingkat perkembangan teknis tertentu dan pada suatu saat tertentu. ${ }^{1}$

Salah satu pemicu terjadinya konflik horizontal di masyarakat adalah bagaimana cara kita berkomunikasi dengan orang lain. Terkadang komunikasi kita dengan orang lain lebih memaksakan kepada kehendak sendiri dimana orang tersebut harus memaksakan orang lain untuk mengikuti budaya komunikasi mereka. Ketika kita berkomunikasi dengan orang lain kita dihadapkan dengan Bahasa-bahasa, aturan-aturan, dan nilai-nilai yang berbeda. Sulit bagi kita untuk memahami komunikasi orang lain bila kita sangat etnosentrik. Menurut Sumner etnosentrisme adalah "memandang segala sesuatu dalam kelompok sendiri sebagai pusat segalanya sesuatu itu, dan hal-hal lainnya diukur dan dinilai berdasarkan rujukan kelompoknya". ${ }^{2}$

Pandangan-pandangan etnosentris tersebut antara lain berbentuk stereotip terhadap suatu kelompok orang, objek, atau peristiwa secara luas yang dianut oleh suatu budaya. Bukan berarti bahwa stereotip itu salah, ada kebenaran dalam stereotip. Jika stereotip digunakan sebagai alat untuk menilai beberapa kelompok atau individu dengan akurat ketika kita baru pertama kali mengenal kelompok tersebut atau tidak sama sekali.

${ }^{1}$ Deddy Mulyanan \& Jalaludin Rakhmat.Komunikas Antar Budaya Panduan Berkomunikasi dengan Orang-Orang Berbeda Budaya (Bandung:PT.Remaja Rosdakarya,2006), 58-63. 18.

${ }^{2}$ Deddy Mulyana, Komunikasi Antar Budaya (Bandung: PT. Remaja Rosdakarya, 2014), 
Namun, bila diterapkan kepada individu tertentu kebanyakan stereotip tidak tepat dan keliru.Masyarakat manapun, cenderung memiliki stereotip-steretip tentang masyarakat lainnya, contohnya di Indonesia, banyak stereotip terbentuk terhadap suatu suku, budaya ataupun agama. Lebih tepatnya, masyarakat Indonesia memiliki penilaian tersendiri dan cenderung digunakan secara baku untuk menggambarkan suatu masyarakat lainnya. Contoh nyatanya adalah penilaian orang pribumi terhadap orang keturunan Tionghoa yang cenderung pelit, komunis, kurang nasionalis, licik dan lain sebagainya.Kemudian, contoh lainnya misalnya penilaian antar suku ataupun bahasa.Orang Indonesia Timur lebih cenderung kasar, keras, mudah terpancing emosinya. ${ }^{3}$

Bercermin dari stereotip-stereotip diatas, untuk bangsa Indonesia, pemahaman komunikasi antarbudaya sangat penting mengingat bangsa kita terdiri dari berbagai suku, bangsa dan ras. Dalam kehidupan sehari-hari, terutama di kota-kota besar interaksi antara satu individu dengan individu lainnya sangatlah intens, apalagi di negara kita di Indonesia terdapat banyak sub-kultur, ras, suku bangsa, agama, latar belakang daerah, latar belakang pendidikan, dan sebagainya. Sekarang masyarakat Indonesia banyak melakukan imigrasi dari satu daerah ke daerah lai, maka dari itu, penting bagi mereka mengetahui asas-asas komunikasi antar budaya guna menciptakan suasana yang aman dan kondusif.

\section{Metode Penelitian}

Penelitian ini merupakan penelitian kualitatif Sesuai dengan obyek kajian tesis ini, maka jenis penelitian ini termasuk dalam kategori penelitian kepustakaan (library research), yaitu, pertama, dengan mencatat semua temuan mengenai motivasi konsumsi secara umum pada setiap pembahasan penelitian yang didapatkan dalam literaturliteratur dan sumber-sumber, dan atau penemuan terbaru mengenai konsep dan dinamika kominkasi antarbudaya di Indonseia. Dengan menggunakan data-data dari berbagai referensi baik primer maupun sekunder. Data-data tersebut dikumpulkan dengan teknik dokumentasi, yaitu dengan jalan membaca (text reading), mengkaji, mempelajari, dan mencatat literatur yang ada kaitannya dengan masalah yang dibahas dalam tulisan ini

Umumnya istilah Studi Kepustakaan digunakan dalam ragam istilah oleh sebagian ahli penelitian. Diantara istilah lain studi kepustakaan yang dikenal adalah kajian pustaka, tinjauan pustaka, kajian teoritis, landasan teori, telaah pustaka (literature review) dan tinjuan teoritis.Penelitian Kepustakaan merupakan jenis penelitian kualitatif yang pada umumnya tidak terjun ke lapangan dalam pencarian sumber datanya. Penelitian Kepustakaan merupakan metode yang digunakan dalam pencarian data, atau cara pengamatan (bentuk observasi) secara mendalam terhadap tema yang diteliti untuk menemukan 'jawaban sementara' dari masalah yang ditemukan di awal sebelum penelitian ditindaklanjuti. Dengan kata lain Penelitian kepustakaan merupakan metode dalam pencarian, mengumpulkan dan menganalisi sumber data untuk diolah dan

\footnotetext{
${ }^{3}$ Alfian, Komunikasi politik dan sistem politik Indonesia (Jakarta: Gramedia Pustaka Utama,
} 1991), 177. 
disajikan dalam bentuk laporan Penelitian Kepustakaan. Penelitian jenis ini salah satunya memuat beberapa gagasan atau teori yang saling berkaitan secara kukuh serta didukung oleh data-data dari sumber pustaka. Sumber pustaka sebagai bahan kajian dapat berupa jurnal penelitian ilmiah, disertasi, tesis, skripsi, laporan penelitian ilmiah, buku teks yang dapat dipertanggungjawabkan asal usulnya, makalah, laporan/kesimpulan seminar, catatan/rekaman diskusi ilmiah, tulisan-tulisan resmi terbitan pemerintah dan lembaga-lembaga lain. Beberapa data-data pustaka tersebut dibahas secara mendalam dan teliti, dalam rangka sebagai pendukung atau penentang gagasan atau teori awal untuk menghasilkan kesimpulan.

Menurut Kaelan, dalam penelitian kepustakaan kadang memiliki deskriptif dan juga memiliki ciri historis. ${ }^{4}$ Dikatakan historis karena banyak penelitian semacam ini memiliki dimensi sejarah, termasuk di dalamyna penelitian agama, misalnya tentang karya tokoh pemikir keagamaan masa lalu seperti imam alGhaza>li@ dan lain sebagainya.Penelitian karya-karya tokoh agama tersebut termasuk penelitian kepustakaan.Penelitian kepustakaan ini bisa meliputi kritik pemikiran, penelitian sejarah agama, dan dapat pula penelitian tentang karya tertentu atau naskah tertentu. Oleh karenanya penelitian kepustakaan akan menghadapi sumber data berupa buku-buku yang jumlahnya sangat banyak sehingga memerlukan motode yang memadai. Untuk itu dalam penelitian kepustakaan, mengumpulkan buku harus secara bertahap, sebab akan kesulitan apabila tidak demikian. Untuk mendapatkan segala kebutuhan tersebut.

\section{Pembahasan}

\section{Konsep Komunikasi}

Komunikasi adalah suatu hubungan yang melibatkan proses ketika informasi dan pesan dapat tersalurkan dari satu pihak (orang / media) ke pihak lain. ${ }^{5}$ Komunikasi berhubungan dengan perilaku manusia dan kepuasan terpenuhinya kebutuhan berinteraksi dengan manusia-manusia lainnya. Hampir setiap manusia membutuhkan hubungan sosial dengan orang lain dan kebutuhan ini terpenuhi melalui pertukaran pesan yang berfungsi sebagai jembatan untuk mempersatukan manusia yang tanpa berkomunikasi akan terisolasi. Pesan muncul lewat perilaku manusia, sebelum perilaku disebut pesan, perilaku harus memenuhi dua syarat.Perilaku harus diobservasi oleh seseorang, dan kedua perilaku harus mengandung makna.Artinya, setiap perilaku yang dapat diartikan atau mempunyai arti adalah suatu pesan.Kedua, perilaku mungkin disadari ataupun tidak disadari (terutama perilaku nonverbal), perilaku yang tidak perilaku itu. ${ }^{6}$ 2010), 134.

${ }^{4}$ Kaelan, Metode Penelitian Agama Kualitatif Interdisipline (Yogyakarta: Paradigma,

${ }^{5}$ Nurani Suyomukti. Pengantar Ilmu Komunikasi (Jogjakarta, AR Ruzz Media,2016), 11.

${ }^{6}$ Deddy Mulyanan \& Jalaludin Rakhmat.Komunikas Antar Budaya Panduan Berkomunikasi dengan Orang-Orang Berbeda Budaya (Bandung: PT. Remaja Rosdakarya, 2006), 12 
Ada beberapa karakteristik yang membantu untuk memahami bagaimana komunikasi yang berlangsung. ${ }^{7}$

sengaja ini menjadi esan bila seseorang melihatnya dan menangkap suatu makna dari Pertama ,komunikasi itu dinamik. Komunikasi adalah suatu aktivitas yang terus berlangsung dan selalu berubah. Sebagai para pelaku komunikasi secara konstan dipengaruhi oleh pesan orang lain dan sebagai konsekuensinya mengalami perubahan yang terus menerus. Setiap orang dalam hidup sehari-hari bertemu dan berinteraksi dengan orang-orang dan orang-orang itu mempengaruhi .setiap kali orang terpegaruh, orang akan berubah, seberapa kecil pun perubahan itu.

1. Kedua, komunikasi itu interaktif, komunikasi terjadi antara sumber dan penerima, ini mengimplikasikan dua orang atau lebih yang membawa latar belakang dan pengalama tersebut mempengaruhi interaksi. Interaksi juga menandakan situasi timbal balik yang memungkinkan setia pihak mempengaruhi pihak lainnya. Setiap pihak secara seentak menciptakan pesan yang dimaksudkan untuk memperoleh respon-respon tertentu dari pihak lainnya.

2. Ketiga, komunikasi tidak dapat dibalik (irreversibble) dalam arti bahwa sekali mengatakan sesuatu dan seseorang telah menerima dan men-decode pesan, tidak dapat menarik kembali pesan itu dan sama sekali meniadakan pengaruhnya. Sekali penerima telah dipengaruhi oleh suatu pesan, pengaruh tersebut tidak dapat ditarik kembali sepenuhnya.

3. Keempat, komunikasi berlangsung dalam konteks fisik dan konteks sosial .ketika interaksi dengan seseorang, interaksi tidaklah terisolasi, tetapi ada dalam lingkungan fisik tertentu dan dinamika sosial tertentu. Lingkungan fisik meliputi objek-objek fisik tertentu.Konteks sosial merupakan hubungan sosial antara sumber dan penerima. Konteks sosial mempengaruhi proses komunikasi, bentuk bahasa yang digunakan, penghormatan yang ditunjukan kepada sesorang, waktu, suasana hati, siapa berbicara dengan siapa dan derajat kegugupan atau kepercayaan diri yang diperhatikan orang, semua itu sebagiam saja dari aspek-aspek komunikasi yang dipengaruhi pleh konteks sosial. Artinya, komunikasi manusia tidak terjadi dalam ruang lingkup sosial,komunikasi terjadi dalam lingkungan sosial yang kompleks.

Lingkungan sosial ini mereflesikan bagaimana orang hidup, bagaimana ia berinteraksi dengan orang lain. Lingkungan sosial adalah budaya, dan bila ingin benar-benar memahami komunikasi, harus memahami budaya. Tidak ada batasan antara budaya dan komunikasi, "Budaya adalah komunikasi dan komunikasi adalah budaya" dengan kata lain ketika membahas komunikasi dan budaya sulit untuk memutuskan mana yang menjadi suara mana yang menjadi gemanya, karena mempelajari budaya melalui komunikasi dan pada saat yang sama komunikasi merupakan refleksi budaya. Budaya adalah suatu konsep yang membangkitkan minat.

\section{6-18.}

${ }^{7}$ Nurani Suyomukti. Pengantar Ilmu Komunikasi (Jogjakarta, AR Ruzz Media,2016), 
Secara formal budaya didefinisikan sebagai tatanan pengetahuan, pengalaman,kepercayaan, nilai, makna, hirarki,agama, waktu, peranan, hubungan ruang, konsep alam semesta, objek-objek materi dan milik yang diperoleh sekelompok besar orang dari generasi ke generasi melalui individu dan kelompok. Budaya menampakan diri dalam pola-pola bahasa dan dalambentuk-bentuk kegiatan dan prilaku yang berfungsi sebagai model-model bagi tindakan penyesuaian diri dan gaya komunikasi yang memungkinkan orangorang tinggal dalam suatu masyarakat disuatu lingkungan geografis tertentu pada suatu tingkat perkembangan teknis tertentu dan pada suatu saat tertentu.

Bahasa adalah seluruh bahasa asing yang ada di dunia. Dalam suatu bahasa tedapat pula dialek, aksen, logat, jargon dan lainnya. Pakaian dan penampilan menyangkut masalah pakaian dan dandanan (perhiasan) luar, serta dekorasi tubuh yang cenderung berbeda secara kultural. Kimono di Jepang, Kebaya di Jawa , Koteka di Papua, payung Inggris, menunjukan beberapa cntoh identitas budaya. seragam polisi, seragam dokter, bentuk riasa, juga meupakan produk budaya yang membedakan budaya satu dengan budaya lainnya. Makanan da kebiasaan makan seperti halnya orang Amerika cenderung menyukai makanan berbahan daging, sedangkan kelompok hindhu menyukai sayuran. Disuatu daerah, meeka makan denganmenggunakan alat makan yang lengkap, sedangkan dikelompok yang lain ada yang menggunakan tangan saja. Budaya orang Jerman menunjukan bahwa mereka lebih tepat waktu dengan orang Amerika yang cenderung lebih santai, hal ini menggambarkan karakteristik waktu dan kesadaran waktu.seorang polisi diberi enghargaan berupa medali atau seorang eksekutif diberi penghargaan, dan cara pemberian penghargaan ini akan berbeda ketika kita berada disubkultur yang berbeda pula.

\section{Hubungan Budaya Dan Komunikasi}

Komunikasi dan kebudayaan tidak sekedar dua kata tetapi dua konsep yang tidak dapat dipisahkan," harus dicatat bahwa studi komunikasi antarbudaya dapat diartikan sebagai studi yang menekankan pada efek kebudayaan terhadap komunikasi. ${ }^{8}$ Menurut Alo liliweri dalam buku dasar-dasar komunikasi antar budaya, komunikasi antarbudaya adalah menambah kata budaya ke dalam pernyataan "komunikasi antara dua orang/ lebih yang berbeda latar belakang kebudayaan"

Beberapa ahli komunikasi antarbudaya mengemukakakn pendapatnya tentang definisi komunikasi antarbudaya sebagai berikut :

1. Andrea L.Rich dan Dennis M.Ogawa menyatakan dalam buku Intercultural Communication,A Reader bahwa komunikasi antarbudaya adalah komunikasi antara orang-orang yang berbeda kebudayaannya, misalnya antara suku bangsa, etnik, ras dan kelas sosial

${ }^{8}$ Alo Liliweri. Dasar-Dasar Komunikasi Antar Budaya ( Yogyakarta:Pustaka Pelajar, 2003), 8. 
2. Samovar dan Porter (1976:4) juga menyatakan komunikasi antarbudaya terjadi diantara produsen pesan dan penerima pesan yang latar belakang kebudayaannya berbeda

3. Chaley H.Dood (1991:5) mengungkapkan komunikasi antarbudaya meliputi komunikasi yang melibatkan peserta komunikasi yang mewakili pribadi, antarpribadi atau kelompok dengan tekanan pada perbedaan latar belakang kebudayaan yang mempengaruhi perilaku komunikasi para peserta. ${ }^{9}$

4. Komunikasi antarbudaya adalah suatu proses komunikasi simbolik, interpretatif,transaksional, dan kontekstual yang dilakukan oleh sejumlah orang yang karena memiliki perbedaan derajat kepentingan memberikan interpretasi dan harapan secara berbeda terhadap apa yang disampaikan dalam bentuk perilaku tertentu sebagai makna yang dipertukarkan. ${ }^{10}$

Dari beberapa pengertian komunikasi antarbudaya dapat disimpulkan bahwa proses komunikasi antarbudaya bahwa semakin besar derajat perbedaan antarbudaya maka semakin besar pula kita kehilangan peluang untuk meramalkan suatu tingkat ketidakpastian Komunikasi sebagai proses (itu salahsatu karakteristik komunikasi) karena komunikasi itu dinamik, selalu berlangsung dan sering berubah-ubah. Sebuah proses terdiri dari beberapa sekuen yang dibedakan namun tidak dapat dipisahkan. Semua sekuen berkaitan satu sama lain meskipu dia selalu berubah-ubah. Jadi pada hakikatnya proses komunikasi lain, yakni suatu proses yang interaktif dan transaksional serta dinamis. ${ }^{11}$

Komunikasi antarbudaya yang interaktif adalah komunikasi yang dilakukan oleh komunikator dengan komunikan dalam dua arah/timbal balik (two way communication) namun masih berada tahap rendah.baik komunikasi interaktif maupun transaksional mengalami proses yang bersifat dinamis, karena proses tersebut berlangsung dalam konteks sosial yang hidup, berkembang dan bahkan berubah-ubah berdasarkan waktu, situasi dan kondisi tertentu. Karena proses komunikasi yang dilakukan merupakan dinamisator atau "penghidup" bagi proses komunikasi tersebut. ${ }^{12}$

Berikut unsur-unsur proses komunikasi antarbudaya ${ }^{13}$ :

a. Komunikator Komunikator dalam komunikasi antar budaya adalah pihak yang memperkasai komunikasi , artinya dia mengawali pengiriman pesan tertentu kepada pihak lain yang disebut komunikan. Dalam komunikasi antarbudaya seorang komunikator berasal dari latar belakang kebudayaan tertentu, misalnya kebudayaan A berbeda dengan komunikan yang berkebudayaan B.

${ }_{9}^{9}$ Alo Liliweri. Makna Budaya dalam Komuinikasi Antarbudaya (Yogyakarta: PT LKIS Printing Cemerlang, 2009), 12.

${ }^{10}$ Alo Liliweri. Makna Budaya dalam Komuinikasi Antarbudaya (Yogyakarta: PT LKIS Printing Cemerlang, 2009), 14. 2003), 24.

${ }^{12}$ Alo Liliweri.Dasar-Dasar Komunikasi Antar Budaya (Yogyakarta:Pustaka Pelajar,

${ }^{13}$ Alo Liliweri. Makna Budaya dalam Komuinikasi Antarbudaya, 27. 
b. Komunikan Komunikan dalam komunikasi antarbudaya adalah pihak yang menerima pesan tertentu. Dia menjadi tujuan/ sasaran komunikasi dari pihak lain (komunikator). Dalam komunikasi antarbudaya, seorang komunikan berasal dari latar belakang sebuah kebudayaan tertentu, misalnya kebudayaan B.

c. Pesan Pesan adalah apa yang ditekankan atau yang dialihkan oleh komunikator kepada komunikan. Setiap pesan sekurang-kurangnya mempunyai dua aspek utama. Content dan Treatment, yaitu isi dan perlakuan. Isi pesan meliputi aspek daya tarik pesan, misalnya kebaruan, kontroversi,argumentatif, rasional bahkan emosional.dan daya tarik pesan saja tidak cukup, akan tetapi sebuah pesan juga perlu mendapatkan perlakuan, perlakuan atas pesan berkaitan dengan penjelasan atau penataan isi pesan oleh komunikator.

d. Media Dalam proses komunikasi antarbudaya, media merupakan tempat, saluran yang dilalui oleh pesan atau simbol yang dikirim melalui media tertulis dan media massa. Akan tetapi kadang-kadang pesan itu dikirim tidak melalui media, terutama dalam komunikasi antar budaya tatap muka.

e. Efek dan umpan balik Manusia mengkomunikasikan pesan karena dia mengharapkan agar tujuan dan fungsi komunikasi itu tercapai. Tujuan dan fungsi komunikasi, termasuk komunikasi antarbudaya, antara lain memberikan informasi, menjelaskan/meguraikan tentang sesuatu, memberikan hiburan, memaksakan pendapat atau mengubah sikap komunikan. Dalam proses tersebut umumnya menghendaki reaksi balikan yang disebut umpan balik. Umpan balik merupakan tanggapan balik dari komunikan kepada komunikator atas pesanpesan yang telah disampaikan. Tanpa umpan balik atas pesan-pesan dalam komunikasi antarbudaya maka komunikator dan komunikan tidak bisa memahami ide, pikiran dan perasaan yang terkadang dalam pesan terkandung dalam pesan tersebut.

f. Suasana (Setting dan Context) Satu faktor penting dalam komunikasi antarbudaya adalah suasana yang kadang-kadang disebut setting of communication, yakni tempat (ruang,space) dan waktu (time) serta suasana (sosial/psikologis) ketika komunikasi antar budaya berlangsung.

g. Gangguan (Noise atau Interference) Gangguan dalam komunikasi antarbudaya adalah segala ssesuatu yang menjadi penghambat laju pesan yang ditukar antara komunikator dengan komunikan, atau yang paling fatal adalah menguraikan makna pesan antarbudaya. Gangguan menghambat komunikan menerima pesan dan sumber pesan. Gangguan (noise) dikatakan ada dalam satu sistem komunikasi bila dalam membuat pesan berbeda dengan pesan yang diterima

Hubungan antara budaya dan komunikasi sangat penting dipelajari untuk memahami komunikasi antar budaya, oleh karena melalui pengaruh budayalah, orangorang belajar untuk berkomunikasi.Komunikasi itu terikat oleh budaya sebagaimana budaya berbeda antara yang satu dengan yang lainnya.Budaya secara pasti mempengaruhi seseorang sejak lahir hingga mati. Bahkan, setelah matipun kita 
dikuburkan sesuai dengan cara-cara budaya kita masing-masing ${ }^{14}$.Budaya dan komunikasi tidak dapat dipisahkan karena budaya tidak hanya menentukan siapa bicara dengan siapa, dan bagaimana orang menanggapi pesan, makna yang ia miliki untuk pesan, dan kondisi-kondisi untuk mengirim memperhatikan dan menafsirkan pesan. Seluruh perilaku individu tergantung bagaimana budaya dan tempat dia dibesarkan.Konsekuensinya, budaya merupakan landasan komunikasi.Bila budaya beraneka ragam maka beraneka ragam pula praktik-praktik komunikasi.

Untuk memahami interaksi antar budaya, pada awalnya kita harus memahami komunikasi individu itu sendiri. Memahami komunikasi manusia berarti memahami apa yang terjadi, apa yang dapat terjadi, akibat-akibat dari apa yang terjadi, dan akhirnya apa yang dapat kita perbuat untuk mempengaruhi dan memaksimalkan hasilhasil dari kejadian tersebut. Komunikasi antar budaya terjadi bila pengirim pesan adalah anggota dari suatu budaya dan penerima pesannya adalah anggota dari suatu budaya lain. ${ }^{15}$

\section{Komunikasi Antarbudaya Dalam Kehidupan Masyarakat Indonesia}

Komunikasi antarbudaya pada dasarnya mampu menghasilkan keselarasan dan kebersamaan.Komunikasi antarbudaya juga memiliki manfaat sebagai salah satu hal yang dapat digunakan untuk memahami sisi perbedaan antarbudaya. Hakikat dari komunikasi antarbudaya ini merupakan kegiatan yang terjadi dalam berkomunikasi pada setiap individu dengan individu lain hingga terbentuknya kemudahan dan pemahaman pada perbedaan-perbedaan yang ada. Adapun beberapa fungsi komunikasi antarbudaya diantaranya:

1. Sebagai penanda identitas sosial. Setiap individu memiliki identitas sosial yang berbeda-beda. Hal ini tergantung kepada seberapa bisa individu menjalankan perannya di sebuah masyarakat. Dengan adanya komunikasi antarbudaya, identitas sosial akan terlihat dan cepat diidentifikasi.

2. Integrasi sosial. Dengan adanya komunikasi antarbudaya tidak hanya membuat masyarakat mengerti satu sama lain namun, dengan adanya komnukasi antar dapat mempersatukan individu satu dengan yang lain dalam interaksi tersebut.

3. Menambah pengetahuan. Komunikasi antarbudaya banyak memberikan pengetahuan-pengetahuan baru kepada individu yang belum memiliki wawasan kepada suatu kebudayaan tertentu.

Selain itu, komunikasi budaya juga memiliki fungsi sosial diantaranya fungsi pengawasan.Pada fungsi ini kegiatan komunikasi antarbudaya berlangsung pada saat komunikator dan komunikan yang berbeda kebudayaan. Fungsi ini lebih banyak digunakan oleh media massa. Kedua, fungsi penghubung. Komunikasi antarbudaya ini juga bisa digunakan sebagai jembatan bagi setiap individu yang memiliki

14 Onong Uchyana Effendy, Imu Komunikasi Teori dan Praktik,( Bandung : Remaja Rosdakarya, 1992).30.

${ }^{15}$ Ali Novel, Peradaban komunikasi politik : Potret Manusia Indonesia, (Bandung : Remaja Rosdakarya, 1999). 89. 
kebudayaan yang berbeda. Pada umumnya, setiap individu yang berbeda atau lebih akan memberikan persepsi mereka yang berbeda-beda. Ketiga, fungsi sosialisasi nilai. Fungsi komunikasi antarbudaya dapat memberikan ajaran dan perkenalan nilai nilai dari suatu kebudayaan masyarakat lain. Dalam artian, seorang individu atau kelompok bisa mengindentifikasi setiap nilai nilai yang ada di suatu kebudayaan lain tanpa harus ikut melibatkan diri pada penerapan nilai-nilai secara langsung. Terakhir, yaitu fungsi menghibur.Dalam hiburan terdapat kegiatan komunikasi antarbudaya.Hal ini dapat ditemukan seperti saat menonton taria, nyanyian bahkan drama sekaligus. ${ }^{16}$

Masyarakat Indonesia merupakan masyarakat dengan kehidupan sosial yang beragam.Hal ini membuat kehidupan masyarakat Indonesia terlihat sangat unik dikarenakan perbedaan tersebut. Keunikan ini jika tidak dimanfaatkan secara benar maka akan menimbulkan benih-benih konflik pada masyarakat. Hal ini sena dengan apa yang disampaikan oleh Al-Qur'an mengenai manusia diciptakan dengan beraneka ragam, bangsa, bahasa, dan warna kulit. Bertolak dari dasar prinsip tentang kemajemukan, Al-Qur'an selanjutnya mempertimbangkan perbedaan lokasi geografis karena manusia hidup berbangsa-bangsa dan bersuku-suku, masing-masing dengan tempat tinggalnya sendiri-sendiri, wajib bagi mereka semua untuk belajar saling mengenal satu sama lain. ${ }^{17}$

Ketika orang-orang berkomunikasi sering timbul salah penafsiran atau kekeliruan hal ini merupakan sesuatu yang wajar. Komunikasi antar budaya dapat terjadi dalam konteks komunikasi manapun mulai dari komunikasi dua orang yang intim hingga komunikasi organisasional dan komunikasi massa.Dewasa ini, komunikasi antar budaya sangat penting untuk dikaji dan diterapkan di Indonesia dibanding dengan masa-masa sebelumnya komunikasi antar budaya dijadikan sebagai ujung tombak dalam mempersatukan perbedaan-perbedaaan yang terdapat pada masyarakat. Menurut De Vito ada beberapa faktor yang menyebabkan pentingnya komunikasi antarbudaya, diantaranya mobilitas, pola imigrasi, saling ketergantungan ekonomi, teknologi komunikasi, dan stabilitas politik. ${ }^{18}$

Seperti yang kita ketahui dalam hal mobilitas masyarakat Indonesia memiliki mobilitas yang sangat tinggi. Orang Indonesia sering melakukan perjalanan tidak hanya dari satu daerah ke daerah lain, namun juga sering berkunjung ke negara-negara seperti belahan benua lain: Eropa, Amerika atau Australia. Hal ini ditambah dengan perkembangan media komunikasi yang semakin pesat.Media sosial seperti Instagram, Facebook dan lainnya memberikan sumbangsih yang besar terhadap mobilitas masyarakat Indonesia.Media sosial seperti magnet yang menarik minat seseorang untuk berkunjung ke suatu tempat setelah melihat postingan di media sosial.Selanjutnya adalah pola imigrasi.Pada pola imigrasi, pada setiap tempat memiliki karakteristik masing-masing beserta dengan konsekuensinya. Hampir di setiap kota besar di dunia kita bisa menjumpai orang-orang dari berbagai negara,

16 Thomas Dye, Politics in States and Communities (New Jersey: Prentice Hall, 2001), 221.

${ }^{17}$ Asep Saepul Muhtadi, Komunikasi Politik Nabdlatul Ulama (Jakarta : LP3ES, 2004),

114.

${ }^{18}$ M Damam Raharjo, Psikologi Komunikasi (Bandung : Rosdakarya, 1994), 56. 
termasuk di kota-kota besar seperti di Indonesia, kita bergaul, bekerja atau bersekolah dengan orang-orang yang berbeda dari latar belakang kita.

Faktor penting lainnya adalah ketergantungan ekonomi, dalam kehidupan sosial setiap individu pasti membutuhkan orang lain. Kebanyakan bergantung secara ekonomi terhadap orang lain. Mungkin masyarakat Indonesia mengenal sistem barter pada zamannya, sekarang masyarakat Indonesia memiliki hubungan perdagangan yang lebih kompleks. Untuk menjalani roda perekonomian, masyarakat membutuhkan komunikasi yang efektif dengan kultur yang berbeda-beda tersebut. Selanjutnya, teknologi komunikasi. Teknologi komunikasi yang berkembang pesat secara tidak sadar telah membawa masuknya kultur luar datang ke Indonesia. Filmfilm produksi Hollywood yang ditayangkan di bioskop telah membuka pikiran kita mengenai budaya orang lain. Kita dapat mengenal kebiasaan dan riwayat hidup bangsa-bangsa lain bahkan kita dengan mudah terhubung dengan siapapun yang berada di belahan dunia manapun melalui koneksi internet.Yang terakhir, stabilitas politik. Stabilitas politik sangat bergantung terhadap stabilitas politik negara lain. Kekacauan politik di belahan dunia lain akan berdampak pada kondisi politik di Indonesia sendiri walaupun tidak signifikan. Maka dari itu, komunikasi dan saling pengertian antar budaya saat ini terasa penting ketimbang dengan masa sebelumnya. ${ }^{19}$

\section{Masalah Komunikasi Sosial Budaya di Indonesia}

Gangguan komunikasi terjadi jika terdapat salah satu elemen komunikasi ,sehingga proses komunikasi tidak dapat berlangsung secara efektif. ${ }^{20}$ sedangkan rintangan komunikasi dimaksudkan ialah adanya hambatan yang membuat proses komunikasi tidak dapat berlangsung sebagaimana harapan komunikator dan komunikan. Gangguan dalam komunikasi antarbudaya adalah segala sesuatu yang menjadi penghambat laju pesan yang ditukar antara komunikator dengan komunikan, atau paling fatal adalah mengurangi makna pesan antarbudaya. Gangguan menghambat komunikan menerima pesan dan sumber pesan .gangguan (noise) dikatakan ada dalam satu sistem komunikasi bila dalam membuat pesan yang disampaikan berbeda dengan pesan yang diterima. Gangguan itu dapat bersumber dari unsur-unsur komunikasi, misalnya komunikator , komunikan, pesan, media/saluran yang mengurangi usaha bersama untuk memberikan makna yang sama atas pesan.

Gangguan komunikasi yang bersumber dari komunikator dan komunikan misalnya karena perbedaan status sosial dan budaya (stratifikasi sosial, jenis perjaan,faktor usia), latar belakang pendidikan (tinggi pendidikan) dan pengetahuan (akumulasi pengetahuan terhadap tema yang dibicarakan), ketrampilan (kemampuan untuk memanipulasi pesan) berkomunikasi. Sementara itu gangguan yang berasal dari pesan misalnya perbedaan pemberian makna atas pesan disampaikan secara verbal,

${ }^{19}$ Jalaludin Rahmat, Metode Penelitian Komunikasi (Bandung : Rosdakarya, 1985), 88.

${ }^{20}$ Hafied Cangara. Pengantar Ilmu Komunikasi ( Raja Grafindp Persada, Jakarta,1998),145. 
(sinonim, homonim, denotatif dan konotatif), perbedaan tafsir atas non verbal (bahasa isyarat tubuh).

De Vito (1997) menggolongkan tiga macam gangguan:

1. Fisik, berupa interfensi dengan transmisi fisik isyarat atau pesan lain, misalnya desingan mobil yang lewat, dengungan komputer, kaca mata.

2. Psikologis, interfensi kognitif atau mental, misalnya prasangka dan bias pada sumber-penerima-pikiran yang sempit.

3. Semantik, berupa pembicara dan pendengar memberi arti berlainan, misalnya orang yang berbicara bahasa yang berbeda, menggunakan jargon atau istilah yang terlalu rumit tidak dipahami pendengar.

Bahasa merupakan interaksi inti manusia.Melalui bahasalah sesorang belajar nilai dan budaya dan perilaku budaya anda. Lagi pula, nama anda merupakan hal penting dalam identitas nasional anda. Bahasa merupakan aspek yang penting dalam belajar komunikasi antarbudaya.Pada dasarnya, bahasa merupakan sejumlah simbol atau tanda yang disetujui untuk digunakan oleh sekelompok orang untuk menghasilkan arti.Hubungan antara simbol dan yang dipilih dan arti yang disepakati kadang berubah-ubah.Bahasa digunakan dalam interaksi komunikasi antarbudaya, hampir setiap interaksi komunikasi antarbudaya melibatkan satu atau lebih individu menggunakan bahasa kedua.Jadi, tidak mungkin untuk membahas semua hal di mana bahasa merupakan faktor yang memberikan hubungan saling menguntungkan pada semua pihak terlibat.

Bahasa dalam interaksi interpesonal, ketika individu dari budaya yang berbeda terlibat dalam komunikasi, jelaslah bahwa seseorang tidak akan menggunakan bahasa asli mereka. Kecuali mereka yang berbicara dalam bahasa kedua fasih atau hampir fasih, potensi untuk salah komunikasi itu tinggi.jadi ketika menggunakan bahasa sendiri dalam suatu interaksi dengan penutur asing, ada beberapa pertimbangan yang harus dimiliki untuk mengurangi kesalahan komunikasi. ${ }^{21}$ Dalam interaksi komunikasi budaya, penting untuk waspada. Hal ini dijelaskan oleh langer sebagai penciptaan kategori baru, mau menerima informasi baru, dan menyadari bahwa orang lain mungkin tidak menyetujui suatu prespektif. Dan salah satu masalah yang dihadapi oleh penutur bahasa kedua adalah bahwa penutur asli kelihatanya berbicara sangat cepat. Selanjutnya adalah kosakata, menentukan kosakata pembicara bahasa kedua juga penting, sampai anda yakin bahwa oranglain telah memiliki kemampuan bahasa kedua yang cukup, anda harus menghindari kosakata tertentu, kata-kata teknik dan singkatan. Metafora slang dan kolokuialisme (istilah ucapan sehari-hari) juga menghambat pemahaman dan sebaliknya tidak digunakan.

Komunikasi yang berlangsung di masyarakat Indonesia sangatlah kompleks karena insan-insan yang terlibat pada proses komunikasi sosial di negeri ini bersifat plural dan heterogen dengan kebhinekaan budaya yang tinggi. Akan tetapi, memang

${ }^{21}$ Larry A.Samovar, Richard E.Porter, Edwin R.Mc Daniel .Komunikasi Lintas Budaya (Jakarta, Salemba Humaika,2010), 267. 
dalam rangka menopang pembangunan nasional terutama pembinaan manusia Indonesia seutuhnya. Fungsi komunikasi tidak hanya berkisar pada masalah bagaimana komunikasi itu bekerja, tetapi juga dan ini hal yang lebih penting, how to communicate (bagaimana cara berkomunikasi) agar terjadi perubahan atau attitude, pandangan dan perilaku pada pihak sasaran komunikasi, apakah sasaran itu seorang individu, kelompok, atau masyarakat keseluruhan.

Perubahan-perubahan sebagai dampak kegiatan komunikasi yang dilakukan si komunikator dapat terjadi karena kesadaran secara emosional, mematuhi peraturanperaturan yang dibuat oleh manusia, bisa juga disebabkan oleh kesadaran secara spiritual mematuhi kaidah-kaidah yang ditentukan oleh agama. ${ }^{22}$

\section{Etnosentris Dan Stereotip Dalam Masyarakat Indonesia}

Secara kurang formal etnosentrisme adalah kebiasaan setiap kelompok untuk menganggap kebudayaan kelompoknya sebagai suatu kebudayaan yang baik.Kita mengasumsikan tanpa berpikir atau berargumen bahwa monogamy adalah lebih baik dari pada poligami, bahwa kaum muda seharusnya memilih pasangannya sendiri, dan bahwa paling baik bila pasangan muda memiliki rumah sendiri. Masyarakat Indonesia pada umumnya adalah masyarakat yang progresif, sedangkan masyarakat di luar dunia barat terbelakang, kesenian kita indah sedangkan kesenian yang lainnya aneh, agama kita benar sedangkan agama yang lain merupakan tahayul. Etnosentrisme membuat kebudayaan kita sebagai patokan untuk mengukur baik buruknya, tinggi rendahnya, dan benar atau tidaknya kebudayaan lain dalam hal proporsi kemiripannya dengan kebudayaan kita. ${ }^{23} \mathrm{Pada}$ dasarnya, etnosentrisme adalah suatu tanggapan manusiawi yang universal, yang ditemukan dalam seluruh masyarakat yang dikenal dalam semua kelompok dan praktisnya dalam seluruh individu.

Meskipun berbagai kelompok budaya, ras, suku, dan agama semakin sering berinteraksi, hal ini tidak otomatis menimbulkan rasa saling pengertian terjalin diantara mereka, karena terdapat prasangka timbal balik antara berbagai kelompok budaya itu. Bila tidak dikelola secara baik, kesalahpahaman antar budaya akan selalu terjadi dan menimbulkan konflik. Ketika kita berkomunikasi dengan orang dari suku, agama, atau ras lain, kita dihadapkan sdengan sistem nilai dan aturan yang berbeda.Sulit memahami komunikasi mereka bila kita memiliki rasa etnosentrik yang kuat.Melekat dalam etnosentrisme ini adalah sebuah stereotip yaitu generalisasi yang biasanya bersifat negatif atas kelompok orang, suku agama ras dengan mengabaikan perbedaan-perbedaan individual.

Di Indonesia sendiri kita sering mendengar stereotip-stereotip kesukuan, misalnya orang jawa dan sunda beranggapan bahwa mereka halus dan sopan dalam berbicara, sedangkan berbeda dengan orang-orang batak yang lebih nekat, suka berbicara keras, dan suka berkelahi.Akan tetapi, orang batak sendiri menganggap

${ }^{22}$ Maswadi Rauf, Indonesia dan Komunikasi Politik (Jakarta : Gramedia Pustaka Utama, 1993), 14.

${ }^{23}$ Budi Sujati, Setia Gumilar, The Voice of the Past suara dari masa silam : teori dan metodologi Sejarah Lisan (Medan : Jurnal JUSPI, Vol. 2 No. 2 Desember 2018),144. 
bahwa mereka pemberani, terbuka, suka berterus terang, pintar, rajin, kuat dan pintar.Mereka menganggap orang-orang sunda lebih halus dan sopan tetapi lemah dan tidak suka berterus terang.Apa yang orang sunda anggap kekerasan, bagi orang batak adalah sebuah kejujuran. Sedangkan apa yang orang sunda anggap kehalusan, bagi orang batak adalah kemunafikan dan kelemahan. ${ }^{24}$

\section{Peranan Bahasa Dalam Komunikasi Antarbudaya}

Kehadiran Bahasa dalam kehidupan manusia tidak dapat dianggap berada dalam suatu ruang hampa.Bahasa merupakan wahana komunikasi utama manusia.Dalam arti luas, Bahasa memiliki dua ciri utama; Bahasa merupakan kode yang penggunaannya ditentukan bersama oleh warga suatu kelompok atau masyarakat.Bahasa disebut berdimensi sosial.Ini berarti, Bahasa merupakan suatu aspek kehidupan sosial manusia.

Bahasa merupakan sebuah lembaga sosial yang dibentuk, dirubah, dan dikembangkan untuk memenuhi kebutuhan kultur atau subkultur yang terus berganti. Karenanya, Bahasa dari budaya satu berbeda dengan Bahasa dari budaya lain, dan sama pentingnya, Bahasa dari suatu dubkultur berbeda dengan Bahasa dari suatu subkultur berbeda dengan Bahasa dari subkultur yang lain. ${ }^{25}$

Dalam pembahasan ini yang dimaksud subkultur adalah kelompok-kelompok dalam sebuah kultur yang besar. Ini dapat didasarkan atas agama, wilayah geografis, pekerjaan, orientasi afeksi, suku bangsa, kebangsaan, kondisi hidup, minat, kebutuhan, dan sebagainya. Islam, Katolik, Kristen, Hindu, dan Budha; Orang Jakarta, Bandung, dan Surabaya, guru, tukang ledeng, dan seniman; kaum heteroseks dan kaum homoseks; Suku Sunda, Suku Jawa, dan Suku Asmat; narapidana, penduduk desa, penduduk kota; pecinta burung, pengumpul prangko, dan pecandu sepak bola;penderita asma, orang buta, dan mantan narapidana, semuanya dapat dipandang sebagai subkultur, bergantung, tentu saja pada konteksnya. ${ }^{26}$

Di Jakarta, misalnya, orang-orang Jakarta jelas bukan subkultur, tetapi di seluruh dunia mereka salah satu subkultur. Masyarakat Jakarta bukanlah subkultur, tetapi ABG (anak baru gede) dan anak gaul di Jakarta adalah subkultur. Seperti yang ditunjukkan oleh contoh-contoh diatas, kaum mayoritas umumnya merupakan kultur, sedangkan berbagai minoritas umumnya merupakan subkultur, tetapi tidak selalu demikian.Dalam Bahasa ini antara kelompok dan subkultur mengacu pada pendapat Samovar dan Porter (Intercultural Communication 1982) disetarakan, karena tidak melihat entitas yang mana menjadi batas antara kelompok dan subkultur, dalam kenyataannya baik bersifat eksklusif maupun terbuka dia hadir di tengah-tengah kultur yang mayoritas.

Menurut Iuli dalam hubungan Bahasa/ budaya tidak terbatas pada kosakata, tata Bahasa, dan ucapan. Realitas berlangsung dalam Bahasa, tak ada realitas di luar

${ }^{24}$ Dedi Mulyana, Metodologi Penelitian Kualitatif, paradigm ilmu komunikasi dan ilmu sosial lainnya (Bandung : Rosdakarya, 2001), 65.

${ }^{25}$ Ibid., hal. 66.

${ }^{26}$ Saifudin, Ahmad Fedyani, Konflik dan Integrasi : Perbedaan paham agama Jakarta : Rajawali, 1986), 35. 
Bahasa. Tak ada cara lain untuk berpikir, baik tentang dunia maupun tujuan-tujuan kita selain mengenai Bahasa.Dalam Samover ruang lingkup Bahasa dalam komunikasi antarbudaya salah satunya adalah interaksi interpersonal yaitu ketika individu dari budaya yang berbeda terlibat dalam komunikasi, jelaslah bahwa tidak akan menggunakan Bahasa asli mereka. Kecuali mereka yang berbicara dalam Bahasa kedua fasih atau fasih, potensi untuk salah komunikasi itu tinggi.Jadi, jika anda menggunakan Bahasa anda sendiri dalam suatu interaksi dengan penutur asing, ada beberapa pertimbangan yang harus anda miliki untuk mengurangi potensi salah komunikasi.

Bahasa merupakan wahana komunikasi utama manusia, menurut Arnold dan Hirsch ada empat fungsi Bahasa yaitu: 1) Sebagai pengenal (identifies), 2) Sebagai wahana interaksi sosial, 3) sebagai katarsis, 4) Sebagai manipulative.

Menurut Alo Iliweri menyebutkan empat fungsi Bahasa, yaitu:

1) Bahasa digunakan untuk menjelaskan dan membedakan sesuatu.

2) Bahasa berfungsi sebagai sarana berinteraksi

3) Bahasa berfungsi sebagai sarana pelepasan tekanan dan emosi

4) Bahasa sebagai sarana manipulatif. ${ }^{27}$

\section{Penutup}

\section{Kesimpulan}

Konsep komunikasi antar budaya di Indonesia merupakan permasalahan di Indonesia. Hal ini membutuhkan hubungan budaya dan komunikasi yang dinamis agar keutuhan bangsa ini tetap selalu terjaga dan menjadi bingkai pemersatu bagi bangsa ini.salah satu cara agar kedinamisan tetap terjaga salah satunya dengan menerapkan model komunikasi antar budaya yang bersifat akomodatif.

Hal itu sangat penting model akomodatif di terapkan di Indonesia karena negara ini merupakan salah satu negara dengan tingkat heterogenitas yang sangat tinggi sehingga aspek kebhinekaan Indonesia yang sudah digagas oleh para pejuang bangsa akan selalu terjaga bahkan bisa menjadi mempererat persaudaraan sesama antar sukusuku bangsadi Indonesia.

Komunikasi budaya yang menjadi tolak ukur dalam merangkul semua elemen suku-suku di Indonesia salah satunya dengan Bahasa.Bahasa Indonesia sudah disepakati oleh founding father kita sebagai Lingua Franca dalam kehidupan berbangsa dan bernegara. Dengan satu Bahasa tersebut bisa untuk menjelaskan dan membedakan sesuatu yang dianggap menjadi permasalahan yang sedang dihadapi oleh bangsa Indonesia, sebagai sarana komunikasi dalam masyarakat, sarana melepaskan tekanan dan emosi rakyat, serta sebagai manipulatif untuk melawan para penghianat bangsa yang berniat menghancurkan negeri ini dari falsafah Pancasila.

${ }^{27}$ Zanden, James W Vander, Social Psychology (NewYork : Random House, 1984), 67. 
56 | Jurnal Dakwah dan Komunikasi, Vol. 4 , No.1, 2019

\section{Daftar Pustaka}

Alfian. 1991. Komunikasi politik dan sistem politik Indonesia. Jakarta : Gramedia Pustaka Utama.

Conway, Margaret M and Frank B Freigert. 2000. Political analysis : An Introduction. Boston : Allyn and Becon Inc.

Dye, Thomas. 2001. Politics in States and Communities. New Jersey : Prentice Hall.

Mulyana, Dedi. 2001. Metodologi Penelitian Kualitatif, paradigm ilmu komunikasi dan ilmu sosial lainnya. Bandung : Rosdakarya.

Mulyana, Deddy. 2014. Komunikasi Antar Budaya. Bandung : PT. Remaja Rosdakarya.

Novel, Ali. 1999. Peradaban komunikasi politik : Potret Manusia Indonesia. Bandung : Remaja Rosdakarya.

Raharjo, M. Damam. 1994. Psikologi Komunikasi. Bandung : Rosdakarya.

Rahmat, Jalaludin. 1985. Metode Penelitian Komunikasi. Bandung : Rosdakarya.

Rauf, Mawadi. 1993. Indonesia dan Komunikasi Politik. Jakarta : Gramedia Pustaka Utama.

Roger dan Shoemaker, (Penj). Daud Abraham, Daud. 1981. Memasyarakatkan ide-ide baru, Jakarta: Ghalia Indonesia.

Saepul Muhtadi, Asep. 2004. Komunikasi Politik Nahdlatul Ulama, (Jakarta : LP3ES, 2004)

Saifudin, Fedyani, Ahmad. 1986. Konflik dan Integrasi : Perbedaan paham agama. Jakarta : Rajawali.

Sujati, Budi. Gumilar, Setia. 2018. The Voice of the Past suara dari masa silam : teori dan metodologi Sejarah Lisan. Medan : Jurnal JUSPI, Vol. 2 No. 2 Desember.

Uchyana Effendy, Onong. 1992. Ilmu Komunikasi Teori dan Praktik.Bandung : Remaja Rosdakarya.

Zanden, Vander, James W. 1984. Social Psychology. New York : Random House. 